\section{Short-term Reductions in Irradiance and Temperature Minimally Affect Growth and Development of Five Floriculture Species}

\author{
Jennifer K. Boldt ${ }^{1}$ \\ Application Technology Research Unit, Greenhouse Production Research \\ Group, USDA-ARS, 2801 W. Bancroft St. MS 604, Toledo, OH 43606
}

Additional index words. angelonia, dianthus, lantana, pansy, petunia, greenhouse, heating, supplemental lighting

\begin{abstract}
Energy inputs are a major production cost for greenhouse-grown plants, especially heating and supplemental lighting. A possible energy-efficient alternative is to optimize greenhouse conditions on days that have a low heating demand and reduce temperature and irradiance on days that have a high heating demand. The objectives of this study were to determine how many days per week annual bedding plants could be grown in a reduced-energy environment before delays in crop growth and flowering occurred and to calculate the potential energy savings. Angelonia (Angelonia angustifolia Benth. 'Angelface Blue'), dianthus (Dianthus chinensis L. 'Telstar Pink'), lantana (Lantana camara L. 'Luscious Citrus Blend'), pansy (Viola $\times$ wittrockiana Gams. 'Matrix Blue Blotch'), petunia (Petunia $\times$ hybrida Vilm. 'Supertunia Mini Strawberry Pink Veined'), and petunia 'Supertunia Vista Bubblegum' were grown in a "winter-normal" (WN) greenhouse $\left(22 / 18^{\circ} \mathrm{C}\right.$ day/night, supplemental lighting from high-pressure sodium (HPS) lamps, 14-hour photoperiod) and transferred to a "winter low-energy" (WLE) greenhouse $\left(13 / 10{ }^{\circ} \mathrm{C}\right.$ day/night, energy curtain continuously closed, day-extension lighting with HPS lamps, 14-hour photoperiod) for $0,1,2,4$, or 7 days per week. In general, days to first flower (DTFF), flower number, plant height, plant width, relative chlorophyll content, and shoot dry weight decreased as exposure duration to WLE increased. Flowering on angelonia was delayed when grown 1 day per week in WLE; delayed on dianthus, petunia 'Supertunia Mini Strawberry Pink Veined', and lantana when grown 4 days per week in WLE; and delayed on petunia 'Supertunia Vista Bubblegum' when grown continuously in WLE. Energy costs were estimated using Virtual Grower 3.0.9, and average savings of $2 \%$ to $8 \%$ occurred with 1 day per week in WLE, and increased to $35 \%$ to $51 \%$ when plants were grown continuously in WLE.
\end{abstract}

Energy inputs are a major production cost for greenhouse-grown plants. Primary energy inputs include heating and supplemental lighting, and they are the third largest expense after labor and plant material (United States Department of Agriculture, 2010). According to the 2009 Census of Horticultural Specialties, energy costs account for $8 \%$ of total production costs in the United States (United States Department of Agriculture, 2010 ). About $65 \%$ to $85 \%$ of total energy consumption is the result of heating (Runkle and Both, 2011).

Many growers maintain static greenhouse day and night air temperature set points, regardless of ambient weather conditions outside. This leads to increased heating costs and energy usage when the heating demand is

Received for publication 30 Sept. 2015. Accepted for publication 1 Feb. 2016.

Mention of a trademark, proprietary product, or company is included for the reader's convenience and does not imply any endorsement or preferential treatment by USDA-ARS.

${ }^{1}$ Corresponding author. E-mail: jennifer.boldt@ ars.usda.gov. high as a result of low outside temperatures, high winds, or lack of solar radiation (Rijsdijk and Vogelezang, 2000). Maintaining the desired temperature only when heating demand is low and lowering the greenhouse air temperature when heating demand is high can help reduce energy use. However, the impact on plant development rate of altering the greenhouse temperature must be considered. Plant development rate in response to temperature is species specific, and it is linear between a base temperature temperature ( $T_{\mathrm{opt}}$; development rate is maximal) (Heins et al., 2000). Decreasing the mean daily temperature has been shown to delay flowering and suppress plant size in annual bedding plants (Blanchard et al., 2011; Miller and Armitage, 2002; Niu et al., 2000). However, few studies have looked at the impact of a reduction in the mean weekly temperature (MWT) in conjunction with fluctuating daily temperatures.

Irradiance is a primary driver of photosynthesis. Therefore, the use of an energy or shade curtain in the greenhouse during the day is a trade-off; it reduces heating losses but limits ambient sunlight to plants. Many $\left(T_{\mathrm{b}}\right.$; development rate $\left.=0\right)$ and an optimum greenhouses, especially those at northern latitudes, use supplemental lighting during winter to augment low solar radiation and improve plant quality. Increasing the daily light integral (DLI), up to a saturation value, can decrease the number of days to flower, increase flower number, and increase shoot dry mass (Blanchard et al., 2011; Faust et al., 2005; Niu et al., 2000). Plant quality is often highest when irradiance and temperature fluctuate in tandem, because of a balance between carbon fixation and carbon use or loss. For example, starch levels in rose (Rosa $\times$ hybrida 'Red Berlin') were similar when plants were exposed to high temperature and high irradiance or low temperature and low irradiance but were noticeably different when the temperature or irradiance exposure occurred in opposition (Dieleman and Meinen, 2007).

One way to reduce energy costs in greenhouse production is to use dynamic heating. It is an effective concept for greenhouses with computerized environmental control systems that can adjust temperatures based on past and forecasted weather conditions to achieve a set mean daily temperature (Dieleman et al., 2005). However, for greenhouses that are not equipped with environmental control systems, one possible energy-efficient alternative is to optimize the growing environment on days that have a lower heating requirement (i.e., warmer, sunnier, and/or less windy) and reduce energy inputs (lower the temperature, turn off supplemental lighting, and close the energy curtain) on days that require more heating. This could be a viable production technique if it does not negatively affect plant growth and crop timing, and provide a cost benefit in the form of reduced energy costs. An initial study conducted in growth chambers (Boldt et al., 2011) indicated minimal impacts to growth, and flowering could be achieved if plants were grown in reduced-energy conditions for $2 \mathrm{~d}$ or less per week, but verification under greenhouse conditions is needed. Therefore, the objectives of this study were 1) to determine how many days per week plants could be grown in a reduced-energy environment before delays in crop growth and flowering occurred and 2) to calculate the potential energy savings that could be achieved.

\section{Materials and Methods}

Plant care. Rooted cuttings of angelonia, lantana, and petunia in 84-cell trays (Pleasant View Gardens, Loudon, NH) and seedlings of dianthus and pansy in 288-count cell trays (Van de Wetering Greenhouses, Jamesport, NY) were received on 6 Feb. 2014. On 10 Feb. and 17 Feb. 2014, the plants were transplanted into $11.5-\mathrm{cm}$-diameter round pots filled with a commercial substrate (LC-1; Sun Gro Horticulture, Bellevue, WA). The transplants were allowed to establish for 1 week before the start of experimental conditions. Greenhouse conditions were $22{ }^{\circ} \mathrm{C}$ day $/ 18{ }^{\circ} \mathrm{C}$ night and ambient irradiance. 
Angelonia and lantana were pinched to two nodes at the start of treatments, and petunias were trimmed and all visible flower buds were removed.

Experimental conditions. Two greenhouse environments were set up within a glass-glazed greenhouse located in Toledo, $\mathrm{OH}$. The WN compartment represented typical greenhouse conditions during winter and early spring. Temperature set points were $22{ }^{\circ} \mathrm{C}$ day $/ 18^{\circ} \mathrm{C}$ night. Highpressure sodium light fixtures (Sunlight Supply, Inc., Vancouver, WA) provided $\approx 100 \mu \mathrm{mol} \cdot \mathrm{m}^{-2} \cdot \mathrm{s}^{-1}$ of supplemental irradiance from 1000-W bulbs (Osram Sylvania Products, Inc., Manchester, NH) when ambient photosynthetic photon flux $(P P F)$ density inside the greenhouse was less than 200 $\mu \mathrm{mol} \cdot \mathrm{m}^{-2} \cdot \mathrm{s}^{-1}$ and a constant $14-\mathrm{h}$ photoperiod (0600-2000 HR) was maintained for the duration of the experiment. Actual supplemental irradiance was $100.1 \pm 24.3$ $\mu \mathrm{mol} \cdot \mathrm{m}^{-2} \cdot \mathrm{s}^{-1}$ (mean $\pm \mathrm{sD}$ ) based on 14 measurements collected using a quantum sensor (MQ-200; Apogee Instruments, Logan, UT) throughout the greenhouse. The WLE compartment represented a cool, low-light environment. Temperature set points were $13{ }^{\circ} \mathrm{C}$ day $/ 10{ }^{\circ} \mathrm{C}$ night, and a spun-woven energy curtain was continuously closed, which reduced ambient irradiance by $\approx 50 \%$, relative to the $\mathrm{WN}$ environment. Day-extension lighting with HPS lamps was provided when ambient irradiance was less than $10 \mu \mathrm{mol} \cdot \mathrm{m}^{-2} \cdot \mathrm{s}^{-1}$ $P P F$ to achieve a constant 14 -h photoperiod. The plants were moved from the WN environment to the WLE environment for $0,1,2$, 4 , or $7 \mathrm{~d}$ per week, every week, until harvest. There were five plants per taxa per treatment and the experiment was replicated 1 week apart. In each environment, aspirated thermocouples measured air temperature and quantum sensors (Model QSO-S; Apogee Instruments) measured $P P F$. These sensors were connected to a data logger (CR10X; Campbell Scientific, Logan, UT) that recorded average temperature and $P P F$ at 15-min intervals. Temperatures and DLIs are provided in Table 1.
Plants were irrigated as needed during the experiment. They were irrigated with reverse-osmosis water once weekly and fertilized at all other irrigation events with $20 \mathrm{~N}-$ 4.4P-16.6K (Jack's 20-10-20; JR Peters, Inc., Allentown, PA) at a $\mathrm{N}$ concentration of $150 \mathrm{mg} \cdot \mathrm{L}^{-1}$. Electrical conductivity and $\mathrm{pH}$ of the substrate solution was monitored weekly on three additional plants of each species grown continuously in the $\mathrm{WN}$ and WLE environments, using the pour-through technique (LeBude and Bilderback, 2009), to ensure values remained within the recommended ranges for all species.

Data collection. Plants were harvested at 4 (petunia), 7 (dianthus and pansy), or 9 (angelonia and lantana) weeks after the start of treatments. Days to first flower and flower number were recorded. Plant height was measured from the substrate surface to the apex (leaf or flower). Plant width was measured at the widest point and perpendicular to the widest point and then the two measurements were averaged. Relative chlorophyll content (CCM-200; Apogee Instruments, Inc.) was collected on three recently matured leaves per plant, and the average value was used for statistical analysis. Aboveground plant tissue was removed, washed with $0.1 \mathrm{~N}$ $\mathrm{HCl}$, rinsed with ultra-purified (18 $\mathrm{M} \Omega$ ) water, dried in a forced-air oven at $60{ }^{\circ} \mathrm{C}$ for $3 \mathrm{~d}$, and weighed.

Estimating energy costs. A virtual greenhouse was constructed to estimate daily heating and supplemental lighting costs for each environment. Greenhouse dimensions, materials, and components were input into Virtual Grower 3.0.9 (USDA-ARS, www. virtualgrower.net). Each greenhouse was located in Toledo, $\mathrm{OH}$, with the following characteristics: single span, $11.0-\mathrm{m}$ long $x$ $8.5-\mathrm{m}$ wide, $3.4-\mathrm{m}$ side height, $5.8-\mathrm{m}$ roof height, triangular glass-glazed roof, $0.9-\mathrm{m}$ foam-insulated knee wall, polycarbonate biwall side and end walls, air exchange rate of $1.65 / \mathrm{h}$, energy curtain (WLE only), forcedair unit heaters burning natural gas, $45 \%$ heating efficiency, and nine 1000-W HPS lamps. Total energy costs for each treatment were calculated as the sum of daily energy costs from the start of the experiment to average date of first flower, based on temperature and supplemental lighting schedules described previously.

Statistical analysis. Data were analyzed as a replicated experiment design, with five treatments, two experiments, and five plants per treatment per experiment. Each plant was an experimental unit, and plants were nested within an experiment and treatment. A separate analysis was conducted for each crop. Data were analyzed in SAS (SAS 9.3; SAS Institute, Inc., Cary, NC) using PROC MIXED and mean separation was conducted with Dunnett's $t$ test at $\alpha=0.05$ for significant treatment effects $(P \leq 0.05)$.

\section{Results}

Days to first flower. Pansy was the only crop in which no delay in flowering occurred on plants grown partially or completely in WLE conditions, relative to WN. Days to first flower ranged between 16 and $22 \mathrm{~d}$ from the start of treatments (Table 2). Flowering on petunia 'Supertunia Vista Bubblegum' was delayed only for plants grown continuously in WLE conditions by $12 \mathrm{~d}$ ( $25 \mathrm{~d}$ in WLE vs. $13 \mathrm{~d}$ in $\mathrm{WN}$ ). Flowering was delayed 8, 8, and $17 \mathrm{~d}$ for dianthus, petunia 'Supertunia Mini Strawberry Pink Veined', and lantana grown $4 \mathrm{~d}$ per week in WLE, respectively, relative to plants grown continuously in WN conditions. Angelonia was the only crop to have a delay in flowering with just $1 \mathrm{~d}$ per week in WLE (6 d). The delay in flowering increased as exposure duration to WLE increased, and angelonia grown continuously in WLE had not flowered 9 weeks after the start of treatments. Flower initiation did occur and buds were present, although they were green and $1-2 \mathrm{~mm}$ in diameter.

Flower number. Flower number at harvest was reduced in all crops exposed to WLE conditions (Table 2). For example, angelonia flower number declined from 72 open flowers per plant in $\mathrm{WN}$ to $57,43,9$, and 0 at $1,2,4$, and $7 \mathrm{~d}$ per week in WLE, respectively. A decrease in flower number was observed in angelonia and both petunia cultivars exposed

Table 1 . Mean weekly temperature $\left({ }^{\circ} \mathrm{C}\right)$ and daily light integral (DLI, mol $\left.\cdot \mathrm{m}^{-2} \cdot \mathrm{d}^{-1}\right)$ for angelonia, dianthus, lantana, pansy, and petunia grown at fluctuating temperature and irradiance. Plants were grown in winter-normal ${ }^{\mathrm{z}}$ conditions and transferred to winter low-energy (WLE) ${ }^{\mathrm{y}}$ conditions for $0,1,2,4$, or $7 \mathrm{~d}$ per week. Plants were harvested 4 (petunia), 7 (dianthus and pansy), or 9 (angelonia and lantana) weeks after the start of treatments.

\begin{tabular}{|c|c|c|c|c|c|c|c|c|}
\hline \multirow{2}{*}{ Parameter } & \multirow{2}{*}{ Days per week in WLE } & \multirow{2}{*}{ Avg weekly temp set point } & \multicolumn{6}{|c|}{ Actual avg weekly temp $\left({ }^{\circ} \mathrm{C}\right)$ and DLI $\left(\mathrm{mol} \cdot \mathrm{m}^{-2} \cdot \mathrm{d}^{-1}\right)$} \\
\hline & & & \multicolumn{2}{|c|}{ Petunia } & \multicolumn{2}{|c|}{ Dianthus/pansy } & \multicolumn{2}{|c|}{ Angelonia/lantana } \\
\hline \multirow[t]{4}{*}{ Temp $\left({ }^{\circ} \mathrm{C}\right)$} & 0 & 20.3 & $20.8 \pm 1.7^{x}$ & $20.9 \pm 1.7$ & $20.7 \pm 1.5$ & $20.9 \pm 1.7$ & $20.9 \pm 1.5$ & $21.0 \pm 1.8$ \\
\hline & 2 & 17.9 & $19.2 \pm 1.5$ & $19.1 \pm 1.5$ & $19.1 \pm 2.0$ & $19.3 \pm 2.3$ & $19.4 \pm 2.6$ & $19.7 \pm 3.5$ \\
\hline & 4 & 15.4 & $17.6 \pm 0.8$ & $17.4 \pm 0.9$ & $17.4 \pm 2.2$ & $17.7 \pm 3.2$ & $18.0 \pm 4.2$ & $18.3 \pm 5.2$ \\
\hline & 7 & 11.8 & $15.1 \pm 1.3$ & $14.7 \pm 1.6$ & $14.9 \pm 3.0$ & $15.4 \pm 5.7$ & $15.9 \pm 7.1$ & $16.4 \pm 8.1$ \\
\hline \multirow[t]{3}{*}{$\operatorname{DLI}\left(\mathrm{mol} \cdot \mathrm{m}^{-2} \cdot \mathrm{d}^{-1}\right)$} & 0 & - & 13.1 & 13.9 & 14.1 & 15.2 & 15.2 & 16.1 \\
\hline & 4 & - & 9.1 & 9.7 & 9.4 & 10.0 & 10.0 & 10.5 \\
\hline & 7 & - & 6.2 & 6.3 & 6.2 & 6.3 & 6.2 & 6.3 \\
\hline
\end{tabular}

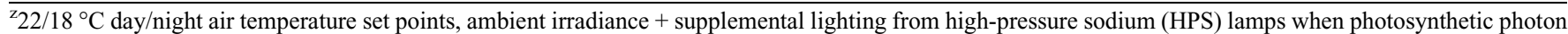
flux $<200 \mu \mathrm{mol} \cdot \mathrm{m}^{-2} \cdot \mathrm{s}^{-1}$, and a 14-h photoperiod.

${ }^{\mathrm{y}} 13 / 10^{\circ} \mathrm{C}$ day/night air temperature set points, a spun-woven energy curtain continuously closed, day-extension lighting from HPS lamps, and a 14-h photoperiod. ${ }^{\mathrm{x}}$ Mean $\pm \mathrm{SD}$. 
Table 2. Plant growth and flowering of angelonia, dianthus, lantana, pansy, and petunia grown at fluctuating temperature and irradiance. Plants were grown in a glass-glazed greenhouse in winternormal $^{\mathrm{z}}$ conditions and transferred to winter low-energy (WLE) ${ }^{\mathrm{y}}$ conditions for $0,1,2,4$, or $7 \mathrm{~d}$ per week. Plants were harvested 4 (petunia), 7 (dianthus and pansy), or 9 (angelonia and lantana) weeks after the start of treatments. Values are the mean $( \pm \mathrm{SE})$ of 10 plants. In each column, for each crop, values followed by an asterisk are significantly different from the control $(0 \mathrm{~d}$ per week in WLE) at $\alpha=$ 0.05 using Dunnett's $t$ test.

\begin{tabular}{|c|c|c|c|c|c|c|c|}
\hline Crop & Trt & DTFF $^{\mathrm{x}}$ & Flower no. & $\mathrm{Ht}(\mathrm{cm})$ & Width $(\mathrm{cm})$ & Dry wt (g) & $\begin{array}{l}\text { Chlorophyll } \\
\text { content index }\end{array}$ \\
\hline \multirow[t]{6}{*}{ Angelonia } & $0 \mathrm{~d}$ & $46 \pm 1$ & $72 \pm 6$ & $35.9 \pm 1.9$ & $44.9 \pm 2.2$ & $13.4 \pm 0.5$ & $67.2 \pm 2.8$ \\
\hline & $1 \mathrm{~d}$ & $52 \pm 1^{*}$ & $57 \pm 10$ & $37.7 \pm 2.2$ & $40.1 \pm 2.3$ & $11.5 \pm 0.7^{*}$ & $58.0 \pm 3.8$ \\
\hline & $2 \mathrm{~d}$ & $54 \pm 1^{*}$ & $43 \pm 8^{*}$ & $37.9 \pm 1.8$ & $32.2 \pm 2.3^{*}$ & $9.6 \pm 0.6^{*}$ & $60.1 \pm 3.3$ \\
\hline & $4 \mathrm{~d}$ & $63 \pm 1^{*}$ & $9 \pm 3^{*}$ & $33.3 \pm 1.1$ & $28.9 \pm 1.1^{*}$ & $5.3 \pm 0.2 *$ & $37.7 \pm 1.7^{*}$ \\
\hline & $7 \mathrm{~d}$ & - & $0 \pm 0^{*}$ & $12.8 \pm 1.1^{*}$ & $16.5 \pm 0.5^{*}$ & $0.9 \pm 0.1^{*}$ & $33.7 \pm 2.0^{*}$ \\
\hline & Diff. $^{\mathrm{w}}$ & 4 & 21 & 6.0 & 5.9 & 1.3 & 10.3 \\
\hline \multirow[t]{6}{*}{ Dianthus } & $0 \mathrm{~d}$ & $34 \pm 1$ & $39 \pm 4$ & $26.8 \pm 1.1$ & $27.5 \pm 0.6$ & $14.3 \pm 0.5$ & $48.3 \pm 2.4$ \\
\hline & $1 \mathrm{~d}$ & $35 \pm 1$ & $29 \pm 4$ & $27.1 \pm 0.6$ & $27.3 \pm 0.8$ & $13.4 \pm 0.7$ & $46.1 \pm 2.5$ \\
\hline & $2 \mathrm{~d}$ & $37 \pm 2$ & $28 \pm 7$ & $28.3 \pm 0.8$ & $27.1 \pm 0.8$ & $11.6 \pm 0.5^{*}$ & $43.9 \pm 3.1$ \\
\hline & $4 \mathrm{~d}$ & $42 \pm 1^{*}$ & $10 \pm 2 *$ & $32.4 \pm 0.7^{*}$ & $25.6 \pm 0.6$ & $8.4 \pm 0.2 *$ & $41.3 \pm 1.6$ \\
\hline & $7 \mathrm{~d}$ & $56 \pm 3^{*}$ & $1 \pm 0 *$ & $32.4 \pm 1.0^{*}$ & $24.8 \pm 0.6^{*}$ & $5.8 \pm 0.3^{*}$ & $35.9 \pm 2.2 *$ \\
\hline & Diff. & 5 & 13 & 3.2 & 2.4 & 1.5 & 8.7 \\
\hline \multirow{6}{*}{ Lantana } & $0 \mathrm{~d}$ & $36 \pm 2$ & $25 \pm 1$ & $23.1 \pm 1.7$ & $59.7 \pm 1.8$ & $12.4 \pm 0.5$ & $45.9 \pm 2.2$ \\
\hline & $1 \mathrm{~d}$ & $35 \pm 2$ & $29 \pm 1^{*}$ & $22.3 \pm 2.0$ & $59.7 \pm 1.8$ & $11.8 \pm 0.5$ & $40.5 \pm 2.0 *$ \\
\hline & $2 \mathrm{~d}$ & $40 \pm 3$ & $25 \pm 1$ & $22.0 \pm 1.1$ & $58.0 \pm 2.1$ & $9.8 \pm 0.3^{*}$ & $33.9 \pm 1.2^{*}$ \\
\hline & $4 \mathrm{~d}$ & $53 \pm 2 *$ & $16 \pm 1^{*}$ & $21.6 \pm 1.3$ & $44.5 \pm 1.3^{*}$ & $6.3 \pm 0.2^{*}$ & $28.2 \pm 1.1^{*}$ \\
\hline & $7 \mathrm{~d}$ & $62 \pm 4^{*}$ & $2 \pm 1^{*}$ & $16.6 \pm 1.1^{*}$ & $31.4 \pm 1.3 *$ & $2.4 \pm 0.3^{*}$ & $23.3 \pm 0.8^{*}$ \\
\hline & Diff. & 10 & 4 & 3.7 & 5.6 & 1.1 & 5.4 \\
\hline \multirow[t]{6}{*}{ Pansy } & $0 \mathrm{~d}$ & $17 \pm 1$ & $17 \pm 1$ & $15.4 \pm 0.6$ & $32.3 \pm 0.6$ & $7.7 \pm 0.2$ & $56.5 \pm 2.1$ \\
\hline & $1 \mathrm{~d}$ & $19 \pm 2$ & $17 \pm 1$ & $14.6 \pm 0.3$ & $33.4 \pm 0.8$ & $7.9 \pm 0.4$ & $55.3 \pm 2.2$ \\
\hline & $2 \mathrm{~d}$ & $16 \pm 1$ & $16 \pm 1$ & $15.8 \pm 0.4$ & $32.9 \pm 1.0$ & $7.2 \pm 0.4$ & $58.4 \pm 3.2$ \\
\hline & $4 \mathrm{~d}$ & $20 \pm 2$ & $8 \pm 1^{*}$ & $14.9 \pm 0.6$ & $28.2 \pm 0.9^{*}$ & $5.1 \pm 0.3^{*}$ & $46.9 \pm 1.6^{*}$ \\
\hline & $7 \mathrm{~d}$ & $22 \pm 3$ & $3 \pm 1 *$ & $13.0 \pm 0.4^{*}$ & $25.0 \pm 0.7 *$ & $3.6 \pm 0.3^{*}$ & $44.5 \pm 2.3 *$ \\
\hline & Diff. & NS & 4 & 1.6 & 2.8 & 1.1 & 8.1 \\
\hline Petunia 'Supertunia & $0 \mathrm{~d}$ & $13 \pm 1$ & $52 \pm 2$ & $20.4 \pm 0.4$ & $51.4 \pm 1.3$ & $10.4 \pm 0.3$ & $32.8 \pm 1.3$ \\
\hline \multirow[t]{5}{*}{ Vista Bubblegum' } & $1 \mathrm{~d}$ & $13 \pm 2$ & $50 \pm 2$ & $19.8 \pm 0.6$ & $47.0 \pm 1.0 *$ & $9.9 \pm 0.3$ & $29.8 \pm 1.5$ \\
\hline & $2 \mathrm{~d}$ & $15 \pm 1$ & $35 \pm 2 *$ & $19.3 \pm 0.6$ & $43.6 \pm 1.0^{*}$ & $8.2 \pm 0.3^{*}$ & $30.1 \pm 1.1$ \\
\hline & $4 \mathrm{~d}$ & $14 \pm 1$ & $19 \pm 3^{*}$ & $18.7 \pm 0.7$ & $35.2 \pm 1.3^{*}$ & $5.9 \pm 0.4^{*}$ & $25.8 \pm 0.9 *$ \\
\hline & $7 \mathrm{~d}$ & $25 \pm 3 *$ & $6 \pm 2 *$ & $15.5 \pm 0.3 *$ & $30.6 \pm 1.6^{*}$ & $4.2 \pm 0.4^{*}$ & $23.1 \pm 0.7^{*}$ \\
\hline & Diff. & 5 & 6 & 1.8 & 3.9 & 0.6 & 3.8 \\
\hline Petunia 'Sup & $0 \mathrm{~d}$ & $21 \pm 1$ & $39 \pm 2$ & - & $51.6 \pm 2.1$ & $8.7 \pm 0.4$ & $42.3 \pm 1.8$ \\
\hline Mini Strawberry & $1 \mathrm{~d}$ & $23 \pm 1$ & $35 \pm 2$ & - & $48.2 \pm 1.8$ & $8.1 \pm 0.3$ & $43.8 \pm 1.8$ \\
\hline \multirow[t]{4}{*}{ Pink Veined' } & $2 \mathrm{~d}$ & $23 \pm 1$ & $27 \pm 2 *$ & - & $41.3 \pm 1.7 *$ & $7.2 \pm 0.2 *$ & $45.1 \pm 2.0$ \\
\hline & $4 \mathrm{~d}$ & $29 \pm 1 *$ & $9 \pm 2 *$ & - & $38.9 \pm 1.3 *$ & $4.8 \pm 0.3 *$ & $44.7 \pm 2.4$ \\
\hline & $7 \mathrm{~d}$ & $44 \pm 3 *$ & $1 \pm 0^{*}$ & - & $36.4 \pm 1.2 *$ & $3.2 \pm 0.2^{*}$ & $34.4 \pm 1.8^{*}$ \\
\hline & Diff. & 6 & 7 & - & 5.5 & 1.0 & 6.8 \\
\hline
\end{tabular}

${ }^{\mathrm{z}} 22 / 18{ }^{\circ} \mathrm{C}$ day/night air temperature set points, ambient irradiance + supplemental lighting from highpressure sodium (HPS) lamps when photosynthetic photon flux $<200 \mu \mathrm{mol} \cdot \mathrm{m}^{-2} \cdot \mathrm{s}^{-1}$, and a $14-\mathrm{h}$ photoperiod.

${ }^{\mathrm{y}} 13 / 10{ }^{\circ} \mathrm{C}$ day/night air temperature set points, a spun-woven energy curtain continuously closed, dayextension lighting from HPS lamps, and a 14-h photoperiod.

${ }^{\mathrm{x}}$ Days to first flower (DTFF) calculated as the number of days since the start of treatments $(7 \mathrm{~d}$ after transplant into $11.5-\mathrm{cm}$ pots).

${ }^{\mathrm{w}}$ Minimum significant difference using Dunnett's $t$ test at $\alpha=0.05$.

to $2 \mathrm{~d}$ per week in WLE and in dianthus, lantana, and pansy exposed to WLE for $4 \mathrm{~d}$ per week, relative to plants grown continuously in WN (Table 2).

Plant height. Angelonia, lantana, pansy, and petunia 'Supertunia Vista Bubblegum' grown continuously in WLE conditions were shorter than plants grown continuously in WN conditions (Table 2). Height was 23.1, 6.5, 2.4, and $4.9 \mathrm{~cm}$ shorter, respectively. Height for these four cultivars grown in WLE conditions up to $4 \mathrm{~d}$ per week was similar to plants grown in WN conditions. Plant height was not measured for petunia 'Supertunia Mini Strawberry Pink Veined' because of its prostrate growth habit. Dianthus plant height increased as exposure duration in WLE increased from $26.8 \mathrm{~cm}$ in $\mathrm{WN}$ to $32.4 \mathrm{~cm}$ in continuous WLE.

Plant width. Plant width was suppressed as exposure to WLE increased (Table 2). to continuous WLE was 53\% (pansy) to $93 \%$ (angelonia) less than plants grown continuously in WN.

Chlorophyll content. Values for chlorophyll content index (CCI) are unitless, so differences are expressed only as relative increases or decreases in chlorophyll content. In general, the CCI of plants grown a few days per week in WLE was similar to those grown continuously in WN conditions, then CCI declined as exposure duration in WLE increased. A decline in CCI was observed at $1 \mathrm{~d}$ per week in lantana; $4 \mathrm{~d}$ per week in angelonia, pansy, and petunia 'Supertunia Vista Bubblegum'; and 7 d per week in WLE in dianthus and petunia 'Supertunia Mini Strawberry Pink Veined', relative to the $\mathrm{WN}$ control for each crop (Table 2).

Energy savings. Using Virtual Grower 3.0.9, energy costs were estimated based on the location, materials, dimensions, and heating and lighting schedules of the greenhouse compartments in which the experiment was conducted. Total energy costs were calculated from the start of the experiment to the mean DTFF for each crop in each treatment. Costs were not estimated for angelonia in the 7-d WLE exposure because plants had not flowered by the time the experiment ended. The percent cost savings, relative to plants grown in the WN control, increased in all crops as the number of days in WLE increased, despite the increased time to flower. Average cost savings were between $2 \%$ and $10 \%$ at $1 \mathrm{~d}$ per week in WLE and increased to $35 \%$ to $51 \%$ when plants were grown continuously $(7 \mathrm{~d}$ per week) in WLE (Table 3).

\section{Discussion}

Plant growth and flowering were negatively affected by increased exposure to WLE, resulting in delayed flowering, fewer flowers, and reduced plant size, mass, and relative chlorophyll content. These plant quality attributes are typically observed in response to reduced temperatures and irradiance. Days to flower for angelonia, pansy, and petunia have been reported to increase in response to decreased temperature (Blanchard et al., 2011; Miller and Armitage, 2002; Niu et al., 2000) and decreased irradiance (Blanchard et al., 2011; Kaczperski et al., 1991; Miller and Armitage, 2002). The delay in flowering is driven primarily by temperature effects on development rate. Although increased irradiance does hasten flowering in some species, it is often attributed to heating of the meristem (Mattson and Erwin, 2005). The reduction in flower number was likely a by-product of both a delay in flowering and reduction in net photosynthesis $\left(\mathrm{P}_{\mathrm{n}}\right)$. Light is a primary driver of photosynthesis, although temperature is a contributing factor to overall $\mathrm{P}_{\mathrm{n}}$. Temperature influences the rate of enzymatic processes and the proportion of fixed carbon lost via photorespiration. For example, Adams et al. (1997) reported an increase in dry matter accumulation 
Table 3. Calculated reduction in energy costs, relative to plants grown continuously in winter-normal $(\mathrm{WN})^{\mathrm{z}}$ conditions. Energy costs were estimated from the start of treatments until mean days to first flower and calculated using Virtual Grower 3.0.9 (Frantz et al., 2010) for a $93.6 \mathrm{~m}^{2}$ glass-glazed greenhouse with polycarbonate bilayer sidewalls located in Toledo, $\mathrm{OH}$. Crops were grown in WN conditions and transferred to winter low-energy (WLE) ${ }^{\mathrm{y}}$ conditions for $0,1,2,4$, or $7 \mathrm{~d}$ per week.

\begin{tabular}{|c|c|c|c|c|c|c|}
\hline \multirow[b]{3}{*}{$\begin{array}{l}\text { Days per } \\
\text { week in WLE }\end{array}$} & \multicolumn{6}{|c|}{$\%$ cost savings } \\
\hline & & & & & Petunia & Petunia \\
\hline & Angelonia & Dianthus & Lantana & Pansy & $\begin{array}{c}\text { Supertunia Vista } \\
\text { Bubblegum }\end{array}$ & $\begin{array}{c}\text { Supertunia Mini } \\
\text { Strawberry Pink Veined }\end{array}$ \\
\hline
\end{tabular}

\begin{tabular}{lrrrrrr}
\hline 0 & - & - & - & - & - & - \\
1 & 3 & 8 & 10 & 2 & 6 & 5 \\
2 & 11 & 13 & 12 & 23 & 8 & 11 \\
4 & 26 & 28 & 20 & 28 & 29 & 20 \\
7 & $-\mathrm{x}$ & 51 & 49 & 51 & 35 & 36 \\
\hline
\end{tabular}

$\mathrm{z}_{22 / 18}{ }^{\circ} \mathrm{C}$ day/night air temperature set points, ambient irradiance + supplemental lighting from highpressure sodium (HPS) lamps when photosynthetic photon flux $<200 \mu \mathrm{mol} \cdot \mathrm{m}^{-2} \cdot \mathrm{s}^{-1}$, and a $14-\mathrm{h}$ photoperiod.

${ }^{\mathrm{y}} 13 / 10{ }^{\circ} \mathrm{C}$ day/night air temperature set points, a spun-woven energy curtain continuously closed, dayextension lighting from HPS lamps, and a 14-h photoperiod.

${ }^{x}$ Plants did not flower by termination of the experiment, 9 weeks after the start of treatments.

in pansy 'Universal Violet' as temperature increased, and it was greatest at $20{ }^{\circ} \mathrm{C}$. Therefore, the reduction in biomass accumulation and plant size in the present study as exposure to WLE increased likely resulted from reduced $\mathrm{P}_{\mathrm{n}}$ because of the lower temperatures and DLIs.

The exposure duration at which reduced growth or delayed flowering occurred varied with species. For example, DTFF was delayed in angelonia after just $1 \mathrm{~d}$ per week in WLE, whereas time to flower in pansy was similar across all treatments. Likewise, a reduction in shoot dry weight was observed in angelonia grown for $1 \mathrm{~d}$ per week in WLE, relative to plants grown continuously in $\mathrm{WN}$, but did not occur until $4 \mathrm{~d}$ per week in WLE for pansy. In addition, the plant quality attribute most sensitive to exposure to WLE differed with species. For example, the initial plant quality attribute affected was plant width for petunia 'Supertunia Vista Bubblegum' ( $1 \mathrm{~d}$ per week WLE), relative chlorophyll content for lantana ( $1 \mathrm{~d}$ per week WLE), and shoot dry weight for dianthus (2 d per week WLE).

Days to flower is one primary determinant of a floricultural crop's marketability and readiness for sale. In this experiment, flowering was delayed by less than $4 \mathrm{~d}$ when plants were grown in WLE for $2 \mathrm{~d}$ per week, except for angelonia which was delayed by $8 \mathrm{~d}$ (Table 2). The delay in flowering was likely the result of reduced temperature, reduced irradiance, or both as exposure duration in WLE increased. Flower development rate (1/ days to flower) in response to temperature is typically linear between $T_{\min }$ and $T_{\mathrm{opt}}$ (Moe and Heins, 1990). Values for $T_{\min }$ of 2.8, 3.9, 4.1 , and $9.9^{\circ} \mathrm{C}$ have been reported for petunia 'Dreams Neon Rose', dianthus 'Super Parfait Raspberry', viola (Viola cornuta L. 'Sorbet Plum Velvet'), and angelonia 'Serena Purple', respectively (Blanchard and Runkle, 2011). Although different cultivars were used in this experiment, the set points for $\mathrm{WN}(22 /$ $18{ }^{\circ} \mathrm{C}$ day/night $)$ and WLE $\left(13 / 10{ }^{\circ} \mathrm{C}\right.$ day/ night) fall between $T_{\min }$ and $T_{\mathrm{opt}}$ for four of the five species evaluated. Although no thermal flowering data have been reported for lantana, it did flower in continuous WLE conditions, which would indicate that $T_{\min }$ is $<10{ }^{\circ} \mathrm{C}$.

Mean weekly temperature decreased from 20.7-21.0 ${ }^{\circ} \mathrm{C}$ to $14.7-16.4{ }^{\circ} \mathrm{C}$ as exposure duration in WLE increased from 0 to $7 \mathrm{~d}$ per week, and a linear relationship between temperature and days to flower was observed for all species except pansy $\left(r^{2}=0.34-0.75\right.$; data not shown). The observed increase in days to flower as exposure duration in WLE increased (and MWT decreased) corresponds with previous studies. For example, Blanchard et al. (2011) reported an increase in time to flower (i.e., a decrease in flower development rate) for petunia 'Easy Wave Coral Pink' and petunia 'Wave Purple' as mean daily temperature decreased from 26 to $14{ }^{\circ} \mathrm{C}$. Likewise, Niu et al. (2000) noted a linear increase in time to flower as average daily temperature decreased from 25.7 to $16.3{ }^{\circ} \mathrm{C}$ and Miller and Armitage (2002) observed an increase in days to flower, from 47 to 58, in angelonia 'Angel Mist Pink' when temperature decreased from 22 to $15^{\circ} \mathrm{C}$.

Mean DLI decreased from 13.1-16.1 $\mathrm{mol} \cdot \mathrm{m}^{-2} \cdot \mathrm{d}^{-1}$ to $6.2-6.3 \mathrm{~mol} \cdot \mathrm{m}^{-2} \cdot \mathrm{d}^{-1}$ as exposure duration in WLE increased from 0 to $7 \mathrm{~d}$ per week, respectively. In many annual bedding plants, an increase in DLI can reduce time to flower and increase plant quality. This likely is a result of an increase in net photosynthetic rate at higher irradiance intensities, resulting in greater carbohydrate availability for growth and development. Blanchard et al. (2011) reported an increase in flower development rate for petunia as mean DLI increased from $4 \mathrm{~mol} \cdot \mathrm{m}^{-2} \cdot \mathrm{d}^{-1}$ to saturation at $\approx 14 \mathrm{~mol} \cdot \mathrm{m}^{-2} \cdot \mathrm{d}^{-1}$. Likewise, Kaczperski et al. (1991) observed that petunia 'Snow Cloud' grown in temperature combinations ranging from 10 to $30{ }^{\circ} \mathrm{C}$ flowered 3 to $23 \mathrm{~d}$ earlier at a given temperature when provided a DLI of $13 \mathrm{~mol} \cdot \mathrm{m}^{-2} \cdot \mathrm{d}^{-1}$ rather than $6 \mathrm{~mol} \cdot \mathrm{m}^{-2} \cdot \mathrm{d}^{-1}$. Miller and Armitage (2002) observed a decrease in days to flower in angelonia 'Angel Mist Pink', from 57 to 45 d, when ambient irradiance was supplemented with $1200 \mu \mathrm{mol} \cdot \mathrm{m}^{-2} \cdot \mathrm{s}^{-1}$.
Chlorophyll content also has been shown to vary in response to temperature and irradiance. In cotton (Gossypium hirsutum L. var. Delta Pine 61), chlorophyll concentration increased from 9.7 to $33 \mu \mathrm{g} \cdot \mathrm{cm}^{-2}$ as temperature increased from 20 to $33{ }^{\circ} \mathrm{C}$ at an irradiance of $1000-1100 \mu \mathrm{mol} \cdot \mathrm{m}^{-2} \cdot \mathrm{s}^{-1}$ and it increased from 11.8 to $39.1 \mu \mathrm{g} \cdot \mathrm{cm}^{-2}$ at an irradiance of $1800-2000 \mu \mathrm{mol} \cdot \mathrm{m}^{-2} \cdot \mathrm{s}^{-1}$, respectively (Winter and Königer, 1991). Chlorophyll concentration in tomato (Solanum lycopersicon L. cv. M-19) and pepper (Capsicum annuum L. cv. M-71) decreased by almost half as the duration of chilling $\left(5^{\circ} \mathrm{C}\right)$ increased from 0 to $12 \mathrm{~d}$ (Javanmardi et al., 2013). Although relative chlorophyll content was measured in this study rather than total chlorophyll concentration, relative chlorophyll content is an accepted proxy for chlorophyll concentration (Ruiz-Espinoza et al., 2010). Although values are unitless, higher values correspond to higher amounts of leaf chlorophyll. A decline in relative chlorophyll content was observed in the present study as exposure duration to WLE increased (Table 2), agreeing with results from previous studies.

In most instances, trends observed for a reduction in plant height, width, and shoot dry weight were consistent across all species and declined as exposure duration to WLE increased. However, dianthus plant height increased as exposure duration increased from $26.8 \mathrm{~cm}$ for plants grown continuously in $\mathrm{WN}$ to $32.4 \mathrm{~cm}$ for plants grown 4 or $7 \mathrm{~d}$ per week in WLE. This is likely the result of decreased irradiance. Variability in shoot height in response to DLI has previously been observed. For example, shoot height of Kalanchoe species increased, decreased, or was unaffected as DLI increased from 4.3 to $17.2 \mathrm{~mol} \cdot \mathrm{m}^{-2} \cdot \mathrm{d}^{-1}$ (Currey and Erwin, 2011). Whereas dianthus height increased, shoot dry weight decreased, resulting in an elongated growth habit.

Estimated energy costs were calculated from the start of treatments to the mean flowering date to account for the lower perday cost in WLE but the extended time of production due to delays in flowering. A net savings in energy was realized in all treatments and ranged from $2 \%$ to $51 \%$ (Table 3 ). Plants grown for $2 \mathrm{~d}$ per week in WLE attained an estimated cost savings of $8 \%$ to $23 \%$. In this treatment, flower delay was minimal ( $<4 \mathrm{~d}$ for most species). A delay in flowering may reduce the number of crop cycles that can be grown in a fixed space over the course of a year and increase a crop's total square-foot-week cost. However, the reduction in plant growth may allow for reduced plant growth regulator use and tighter crop spacing. Combined with a reduction in energy usage, this could offset any additional costs incurred. This may be especially relevant for crops that do not show a large delay in flowering due to a reduction in temperature and $P P F$ (e.g., pansy, petunia, and dianthus).

In conclusion, some plants can be grown for 1 or more days per week in WLE conditions without a marketable impact to 
plant quality or time to flower. Cold-sensitive crops, such as angelonia, can be grown successfully, but only if exposure durations are limited to $1 \mathrm{~d}$ per week. Overall, results from this study indicate that it can be worthwhile for growers in the northern United States to increase the temperature set point slightly on sunny, winter days and use supplemental lighting and minimize energy outflow (energy curtain closed, no supplemental lighting, and a reduced temperature set point) on cold, cloudy days to reduce energy costs.

\section{Literature Cited}

Adams, S.R., S. Pearson, and P. Hadley. 1997. An analysis of the effects of temperature and light integral on the vegetative growth of pansy cv. Universal Violet (Viola $\times$ wittrockiana Gams.). Ann. Bot. 79:219-225.

Blanchard, M.G. and E.S. Runkle. 2011. Quantifying the thermal flowering rates of eighteen species of annual bedding plants. Scientia Hort. 128:30-37.

Blanchard, M.G., E.S. Runkle, and P.R. Fisher. 2011. Modeling plant morphology and development of petunia in response to temperature and photosynthetic daily light integral. Scientia Hort. 129:313-320.

Boldt, J.K., E.Y. Gesick, M.H. Meyer, and J.E. Erwin. 2011. Alternative periodic energy-efficient light and temperature strategies for herbaceous ornamental production. HortScience 46:S354 (abstr.).

Currey, C.J. and J.E. Erwin. 2011. Photosynthetic daily light integral impacts growth and flowering of several kalanchoe species. HortTechnology 21:98-102.

Dieleman, J.A. and E. Meinen. 2007. Interacting effects of temperature integration and light intensity on growth and development of single-stemmed cut rose plants. Scientia Hort. 113:182-187.

Dieleman, J.A., E. Meinen, L.F.M. Marcelis, H.F. de Zwart, and E.J. van Henten. 2005. Optimisation of $\mathrm{CO}_{2}$ and temperature in terms of crop growth and energy use. Acta Hort. 691:149154.

Faust, J.E., V. Holcombe, N.C. Rajapakse, and D.R. Layne. 2005. The effect of daily light integral on bedding plant growth and flowering. HortScience 40:645-649.

Frantz, J.M., B. Hand, L. Buckingham, and S. Ghose. 2010. Virtual Grower: Software to calculate heating costs of greenhouse production in the United States. HortTechnology 20:778-785.

Heins, R.D., B. Liu, and E.S. Runkle. 2000. Regulation of crop growth and development based on environmental factors. Acta Hort. 511:1524.

Javanmardi, J., M. Rahemi, and M. Nasirzadeh. 2013. Physiological and reproductive responses of tomato and pepper transplants to low-temperature conditioning. Intl. J. Veg. Sci. 19:294-310.

Kaczperski, M.P., W.H. Carlson, and M.G. Karlsson. 1991. Growth and development of Petunia xhybrids as a function of temperature and irradiance. J. Amer. Soc. Hort. Sci. 116:232237.

LeBude, A.V. and T.E. Bilderback. 2009. The pour-through extraction procedure: A nutrient management tool for nursery crops. N.C. State Univ. Coop. Ext. Pub. AG-717-W.

Mattson, N.M. and J.E. Erwin. 2005. The impact of photoperiod and irradiance on flowering of several herbaceous ornamentals. Scienta Hort. 104:275-292.

Miller, A. and A.M. Armitage. 2002. Temperature, irradiance, photoperiod, and growth retardants influence greenhouse production of Angelonia angustifolia Benth. Angel Mist series. HortScience 37:319-321.

Moe, R. and R. Heins. 1990. Control of plant morphogenesis and flowering by light quality and temperature. Acta Hort. 272: 81-90.

Niu, G., R.D. Heins, A.C. Cameron, and W.H. Carlson. 2000. Day and night temperatures, daily light integral, and $\mathrm{CO}_{2}$ enrichment affect growth and flower development of pansy (Viola Xwittrockiana). J. Amer. Soc. Hort. Sci. 125:436-441.

Rijsdijk, A.A. and J.V.M. Vogelezang. 2000. Temperature integration on a 24-hour base: A more efficient climate control strategy. Acta Hort. 519:163-169.

Ruiz-Espinoza, F.H., B. Murillo-Amador, J.L. García-Hernández, L. Fenech-Larios, E.O. Rueda-Puente, E. Troyo-Diéguez, C. Kaya, and A. Beltrán-Morales. 2010. Field evaluation of the relationship between chlorophyll content in basil leaves and a portable chlorophyll meter (SPAD-502) readings. J. Plant Nutr. 33:423438.

Runkle, E. and A.J. Both. 2011. Greenhouse energy conservation strategies. Mich. State Univ. Ext. Bull. E-3160.

United States Department of Agriculture. 2010. 2007 Census of agriculture: Census of horticultural specialties (2009). AC-07-SS-3. 8 Aug. 2015. <http://www.agcensus.usda. gov/Publications/Census_of_Horticulture_ Specialties/>.

Winter, K. and M. Königer. 1991. Dry matter production and photosynthetic capacity in Gossypium hirsutum L. under conditions of slightly suboptimum leaf temperatures and high levels of irradiance. Oecologia 87:190 197. 